\title{
KAJIAN PENGELOLAAN DANA OTONOMI KHUSUS DI KABUPATEN ASMAT
}

\author{
Anthonius H Citra Wijaya ${ }^{4}$ \\ anthoniuscitra@gmail.com
}

\begin{abstract}
The aims of this study were to: (1) identify and review issues and aspects in financial planning and management of Special Autonomy Fund in delivering education and health services as well as formulate alternative policies to improve financial planning and management funded by Papua Special Autonomy Fund in Asmat regency. A case study approach was applied in this study using multiple case designs. Population to be observed in this study was the whole social organization, government offices and legislative institutions located in the regency of Asmat. The sampling technique used was multistage non random sampling. The results showed low level of accountability in reporting the use of Special Autonomy Funds. This pointed out the lack of desire from Asmat regency for implementation of transparency of financial reporting. Lack of transparency in the use of special autonomy funds could negatively impact at large scales which could be detrimental to societies, particularly in the Asmat regency. Special Autonomy Fund allocation for the education sector was not complied with the mandate of Special Regional Regulation No. 25 in 2013 titled Revenue Distribution and Financial Management of the Special Autonomy Fund. The education sector was being allocated for the fund 27.03 per cent on average despite the regulation mandate which was 30 per cent. On the other hands, the special autonomy fund allocation for health sector was complied with the regulation which was 15 per cent.
\end{abstract}

Key Words: Papua, Asmat, Special Autonomy Fund

\section{PENDAHULUAN}

Selama pelaksanaan Otonomi Khusus (Otsus), Provinsi Papua telah menerima dana dalam jumlah besar yang berasal dari 2 persen dari total DAU Nasional. Dalam kurun waktu tahun 2002-2012 Jumlah total dana sebesar Rp33,7 trilyun dana Otsus dan dana infrastruktur telah disalurkan ke daerah. Sesuai dengan ketentuan Pasal 34 UU 21/2001 tentang Otonomi Khusus bagi Provinsi Papua, dana yang disalurkan dalam rangka Otsus Papua harus dialokasikan untuk membangun dan

\footnotetext{
${ }^{4}$ Staf dosen Jurusan Akuntansi Fakultas Ekonomi dan Bisnis Universitas Cenderawasih
} 
mengejar ketertinggalan Papua, khususnya penduduk asli Papua. Target dan sasaran yang menjadi perhatian adalah bidang pendidikan, kesehatan, infrastruktur, dan perekonomian rakyat. Dana ini dialokasikan setiap tahun dari APBN dan ditransfer dalam 3 sampai 4 kali ke kas daerah milik Pemerintah Provinsi Papua. Sesuai ketentuan UU 21/2001 dana ini juga dibagikan ke kabupaten/kota di Provinsi Papua.

Institusi pemerintahan banyak dituding sebagai lembaga yang paling bertanggungjawab atas masalah pengelolaan keuangan Otsus (Salle, 2011). Kesalahan pertama dialamatkan kepada Pemerintah Daerah Provinsi Papua dan DPRP, antara lain karena regulasi yang mengatur pengelolaan dana Otsus, dan merupakan tanggungjawab Pemda Provinsi Papua, sampai saat ini belum ditetapkan. Selain itu warga sering mengangkat masalah rendahnya transparansi pengalokasian dana Otsus, pengalokasian untuk bidang pendidikan dan kesehatan, bantuan keuangan dan prsarana kepada pengusaha informal (mama-mama Papua), dan sebagainya. Kesalahan kedua dialamatkan ke Pemerintah kabupaten dan kota yang ikut dinilai telah memanfaatkan dana untuk kepentingan pribadi dan mengalokasikan dana melenceng dari tujuan untuk memajukan pelayanan dasar. Banyak pimpinan dan pejabat daerah tertentu dinilai menghambur-hamburkan uang rakyat dari sumber dana Otsus saat bepergian ke luar daerah. Pelayanan publik sangat kurang karena banyak pimpinan dan pejabat daerah, termasuk anggota dewan hanya menghabiskan waktu di luar daerah mereka. Kesalahan ketiga dialamatkan pada Pemerintah. Pemerintah juga ikut dipersalahkan karena dinilai tidak mengawasi dan memberi panduan atau arahan pengelolaan dana dana Otsus. Pemerintah dinilai sengaja membiarkan masalah pengelolaan dan penyalahgunaan dana Otsus. Sejak awal Pemerintah mengetahui bahwa pengelolaan dana Otsus harus diatur dengan Perdasus, tetapi Pemerintah tidak memberi sanksi atas kelalaian menyusun Perdasus. Wacana publik yang menginginkan agar dana Otsus dikelola terpisah dari sumber dana lain tidak pernah 
difasilitasi atau pun dijelaskan. Hal ini membuat kebingungan berkepanjangan di Papua.

Alokasi dana yang sangat besar untuk pendidikan dan kesehatan seharusnya sudah dapat memperbaiki pelayanan bagi penduduk asli Papua baik yang ada di kampung-kampung maupun perkotaan. Namun ternyata dari sejumlah indikator pendidikan dan kesehatan ternyata perbaikan untuk kedua bidang ini belum sesuai yang diharapkan. Dalam bidang pendidikan indikator buta huruf Papua terus meningkat. Persentase penduduk buta huruf untuk usia sekolah (umur sampai 15 tahun) meningkat dari 24,94 persen pada tahun 2003 menjadi 35,92 persen pada tahun 2011. Umur produktif (15-14 tahun) persentasenya juga masih sangat besar. Umur produktif yang buta huruf di Papua pada tahun 2011 mencapai 34,83 persen dari jumlah penduduk. Indikator ini sangat buruk dibanding rata-rata Indonesia yang hanya 2,30 persen. Masalah bidang kesehatan yang banyak disoroti adalah masih kurangnya prasarana dan sarana Puskesmas dan Pustu. Kepala Dinas Kesehatan Provinsi Papua memperkirakan masih 2600 kampung yang belum mempunyai Pustu. Kalau Pustu saja tidak ada di daerah itu, juga dipastikan tenaga kesehatan tidak ada di kampung-kampung itu. Bila diukur dari keberadaan prasarana kesehatan, cakupan pelayanan kesehatan di Papua diperkirakan baru mencapai 29 persen (1.000 kampung dari total 3.500 kampung).

Semua fakta di atas kemudian menimbulkan tanda tanya dan keraguan masyarakat, yaitu "kemana uang Otsus itu?" Penelitian ini diarahkan untuk menjawab pengelolaan keuangan Otsus dalam bidang kesehatan dan pendidikan, yaitu perencanaan dan pengelolaannya, masalah yang dihadapi, dan kebijakan apa yang dapat ditempuh untuk memperbaiki perencanaan dan pengelolaan dana Otsus bidang pendidikan dan kesehatan di Kabupaten Asmat. 
Penelitian ini bertujuan untuk mengidentifikasi dan meriviu masalah perencanaan dan pengelolaan keuangan yang bersumber dari Dana Otsus untuk pelayanan pendidikan dan kesehatan; lalu mengidentifikasi dan meriviu aspek perencanaan dan pengelolaan keuangan yang bersumber dari Dana Otsus untuk peningkatan pelayanan dasar pendidikan dan kesehatan; selain itu juga untuk merumuskan alternatif kebijakan untuk perbaikan perencanaan dan pengelolaan keuangan yang bersumber dari dana Otonomi Khusus Papua di Kabupaten Asmat untuk peningkatan pelayanan pendidikan dan kesehatan. Sedangkan manfaatnya adalah agar penelitian ini dapat memberi kontribusi (manfaat) dalam penyusunan kebijakan Pemerintah Kabupaten Asmat untuk menjawab berbagai permasalahan pengelolaan Dana Otsus. Sejumlah fenomena dan permasalahan yang berhasil diidentifikasi dalam penelitian ini dapat digunakan sebagai data dan informasi untuk merumuskan kebijakan yang lebih komprehensif untuk pengelolaan Dana Otsus dalam bidang pendidikan dan kesehatan; yang kemudian dapat direplikasi untuk bidang prioritas lainnya.

\section{METODE PENELITIAN}

\section{Disain Penelitian}

Pendekatan yang digunakan kajian ini adalah studi kasus (case study). Literatur menjelaskan dua bentuk kasus yaitu, kasus tunggal (single case) dan kasus jamak (multiple cases). Eisenhardt (1989, p. 534) menjelaskan bahwa studi kasus tunggal dan kasus jamak telah berhasil dipakai untuk membangun teori-teori baru. Studi ini menggunakan desain kasus jamak.

\section{Prinsip Dasar Kajian}

Prinsip dasar yang digunakan dalam kajian ini adalah merumuskan rekomendasi kebijakan dalam pengelolaan dana otsus untuk meningkatkan pelayanan dari pemerintah daerah terhadap masyarakat asli Papua khususnya di bidang pendidikan, kesehatan dan gizi, 
infrastruktur dasar kampung, dan pemberdayaan ekonomi masyarakat, berdasarkan prinsip-prinsip efektifitas, partisipatif, transparansi dan akuntabilitas.

\section{Pendekatan Kajian}

Secara garis besarnya pendekatan penelitian yang digunakan dalam kajian ini adalah mixed method research. Model yang digunakan adalah triangulasi yang bertujuan untuk memperoleh data yang berbeda tetapi saling melengkapi (complementary) dalam mengamati dan mengkaji masalah-masalah penelitian pada topik yang sama.

Pendekatan kuantitatif dalam kajian ini digunakan untuk: mempelajari berbagai kecenderungan, meramalkan dampak kebijakan yang diambil dan memperkirakan persoalan-persoalan yang potensial terjadi, serta menjadi dasar pertimbangan dalam pengembangan berbagai alternatif rencana yang akan diambil. Dalam hal ini obyek yang diamati tidak perlu diberi perlakuan sebagaimana halnya dengan penelitian eksperimental. Pengamatan dilakukan hanya untuk menelusuri peristiwa-peristiwa yang secara empiris telah terjadi, kemudian merunut kebelakang melalui data tersebut untuk mengungkap faktor-faktor penyebab terjadinya peristiwa yang diamati. Metode yang digunakan dalam pendekatan ini adalah deskriptif yang mempunyai tujuan untuk mendeskripsikan secara sistematis, aktual dan akurat mengenai fakta-fakta dan sifat-sifat populasi atau daerah tertentu.

Metoda yang diterapkan dalam pendekatan kualitatif adalah FGD (Focus Group Discussion). Ada beberapa pertimbangan mengapa teknik FGD digunakan dalam kajian ini yaitu (1) melalui FGD akan diperoleh informasi-informasi penting dan lebih mendalam mengenai faktor-faktor apakah yang menyebabkan pengaruh dari suatu variabel terhadap variabel lainnya yang diamati lebih besar atau kecil, (2) FGD dapat menstimulasi ide-ide dan konsep baru berdasarkan temuan dari model kuantitatif, dan (3) dengan FGD dapat ditafsirkan hasil-hasil evaluasi 
secara lebih baik, serta mempelajari perilaku dan keinginan dari masyarakat yang dinilai.

\section{Fokus dan Lokus Penelitian}

Topik penelitian sosial mengandung unsur fokus dan lokus. Fokus berkenaan dengan satu pokok masalah atau pokok perhatian di antara beberapa atau banyak masalah yang berkaitan dengan bidang/disiplin ilmu tertentu. Sedangkanlokus berkenaan dengan tempat terjadinya masalah atau tempat dilaksanakan penelitian atas suatu masalah.

Tabel 1

Fokus dan Lokus Penelitian

\begin{tabular}{|c|c|c|c|c|c|}
\hline \multicolumn{2}{|c|}{ Fokus Bidang/Disiplin IImu } & \multicolumn{4}{|c|}{ Lokus Penelitian } \\
\hline Perencanaan & Penganggaran & $\begin{array}{c}\text { Organisasi } \\
\text { Sosial }\end{array}$ & SKPD & Legislatif & Individu \\
\hline $\begin{array}{l}\text { - Penetapan } \\
\text { Sasaran } \\
\text { Strategis } \\
\text { - Penetapan } \\
\text { output dan } \\
\text { outcome } \\
\text { - Penetapan } \\
\text { Indikator } \\
\text { Kinerja } \\
\text { Otsus }\end{array}$ & $\begin{array}{l}\text { - Penetapan } \\
\text { kebutuhan } \\
\text { anggaran } \\
\text { Otsus } \\
\text { - Penetapan } \\
\text { prioritas } \\
\text { anggaran } \\
\text { Otsus } \\
\text { - Pelaksanaan } \\
\text { anggaran } \\
\text { - Pertanggung } \\
\text { jawaban } \\
\text { anggaran }\end{array}$ & $\begin{array}{l}\text { - Sekolah } \\
\text { - Kelompok } \\
\text { belajar } \\
\text { - Puskesmas } \\
\text { - Rumah } \\
\text { Sakit } \\
\text { - LSM } \\
\text { - Asosiasi }\end{array}$ & $\begin{array}{l}\text { - Bappeda } \\
\text { - Pendidikan } \\
\text { - Kesehatan } \\
\text { - SKPD } \\
\text { Lainnya yang } \\
\text { terkait } \\
\text { dengan } \\
\text { sektor } \\
\text { pendidikan } \\
\text { dankesehatan }\end{array}$ & $\begin{array}{l}\text { - DPRP } \\
\text { - MRP }\end{array}$ & $\begin{array}{l}\text { - Guru } \\
\text { - Dokter } \\
\text { - Rumah } \\
\text { tangga } \\
\text { - Tokoh } \\
\text { Adat } \\
\text { dan } \\
\text { Agama }\end{array}$ \\
\hline
\end{tabular}

\section{Populasi, Sampel dan Teknik Sampling}

Sesuai dengan ruang lingkup wilayah dan lokus penelitian yang telah ditetapkan, maka populasi yang akan diamati dalam kajian ini adalah seluruh organisasi sosial, SKPD dan lembaga legislatif yang berada di 
wilayah Kabupaten Asmat. Teknik sampling yang digunakan adalah multistage non random sampling. Teknik ini adalah mengambil sampel melalui beberapa tahap, hingga tahap yang dianggap jenuh, serta dilaksanakan secara non random. Tahapan pertama yaitu menentukan wilayah distrik sampel yang merupakan ibukota kabupaten. Lalu, setiap distrik ditetapkan sampel kampung/kelurahan yang akan diamati sebanyak 2 kampung/kelurahan, yaitu kampung/kelurahan yang menjadi ibukota distrik, dan satu kampung lainnya yang letaknya tidak lebih dari $100 \mathrm{~km}$ dari ibukota distrik serta mudah dijangkau melalui darat.

\section{Kerangka Analisis}

Kerangka analisis dari studi ini diawali dengan mengamati sistem perencanaan yang dilaksanakan dalam penggunaan dana Otsus yang disusun berdasarkan regulasi dan peraturan yang berlaku. Selanjutnya dilihat apakah ada integrasi yang baik antara perencanaan dengan pendanaan atau penganggaran yang bersumber dari Otsus. Setelah ditelusuri keterkaitan antara perencanaan dan penganggaran, tahap berikutnya adalah mengamati bagaimana pelaksanaan anggaran dana Otsus tersebut dilakukan, dimana ada 4 aspek yang menjadi fokus yaitu pelaksanaan anggaran, monitoring dan evaluasi, penatausahaan dan akuntansi, serta pelaporan dan tindak lanjut.

Seluruh tahapan penggunaan dana Otsus tersebut, mulai dari perencanaan, penganggaran, hingga pelaksanaan anggaran, akan dilihat apakah telah menggunakan asas partisipasi, transparansi dan akuntabilitas. Sehingga nantinya dapat dinilai lebih jauh bagaimana efektifitas penggunaan dana Otsus terhadap upaya untuk meningkatkan pelayanan terhadap masyarakat Orang Asli Papua yang diwujudkan sebagai output, outcome dan impact. 


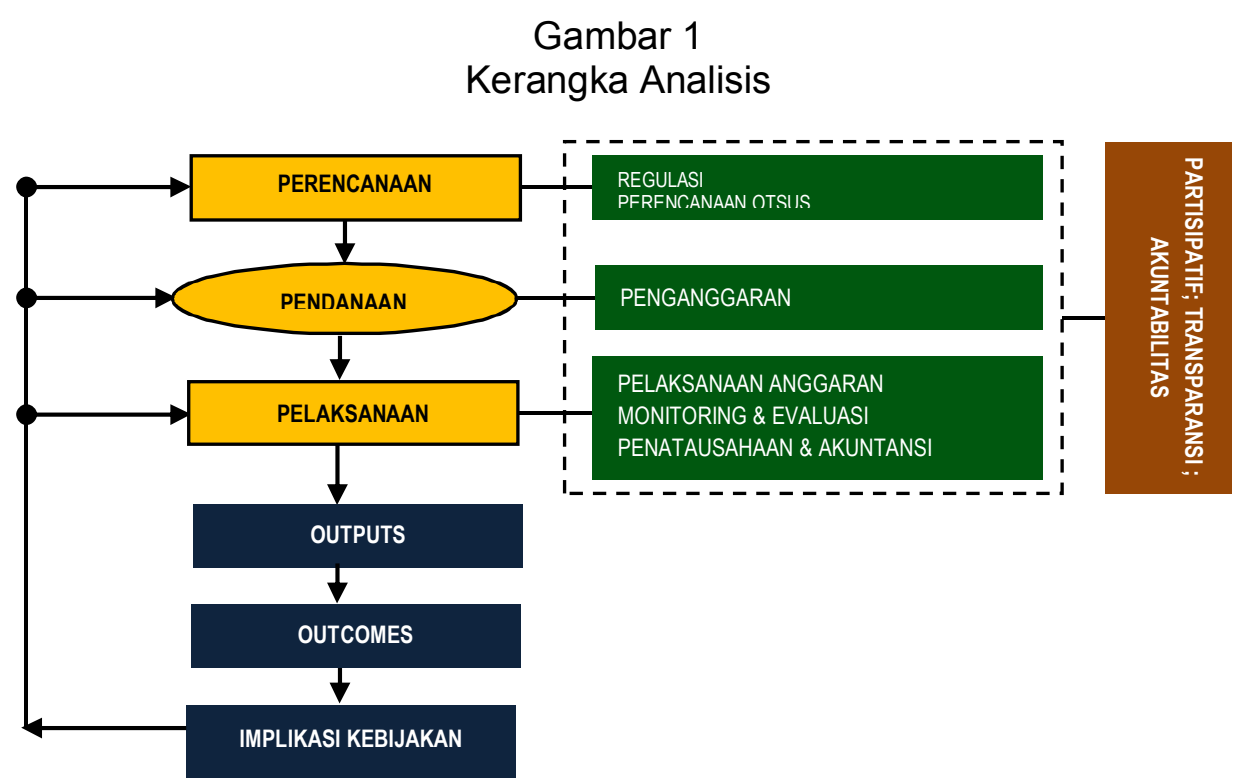

\section{Definisi Konsep}

\section{Partisipasi}

Ada dua macam definisi tentang partisipasi (rakyat) masyarakat dalam pembangunan, yaitu: pertama, partisipasi rakyat dalam pembangunan sebagai dukungan rakyat terhadap rencana/proyek pembangunan yang dirancang dan ditentukan tujuannya oleh perencana. Ukuran tinggi rendahnya partisipasi rakyat dalam definisi ini diukur dengan kemauan rakyat untuk ikut bertanggungjawab dalam pembiayaan pembangunan, baik berupa uang maupun tenaga dalam melaksanakan proyek pembangunan pemerintah. Kedua, partisipasi rakyat merupakan kerjasama yang erat antara perencana dan rakyat, dalam merencanakan, melaksanakan, melestarikan dan mengembangkan hasil pembangunan yang telah dicapai. Ukuran tinggi rendahnya partisipasi rakyat tidak hanya diukur dengan kemauan rakyat untuk menanggung biaya pembangunan, tetapi juga dengan ada tidaknya hak rakyat untuk ikut menentukan arah dan tujuan proyek yang akan dibangun di wilayah mereka.

Partisipasi sebagai salah satu elemen pembangunan merupakan proses adaptasi masyarakat terhadap perubahan yang sedang berjalan. 
Dengan demikian partisipasi mempunyai posisi yang penting dalam pembangunan. Prasyarat yang harus terdapat dalam proses pembangunan berkelanjutan adalah dengan mengikutsertakan semua anggota masyarakat/rakyat dalam setiap tahap pembangunan.

Ada tiga alasan utama sangat pentingnya partisipasi masyarakat dalam pembangunan, yaitu: (1) Partisipasi masyarakat merupakan suatu alat guna memperoleh informasi mengenai kondisi, kebutuhan dan sikap masyarakat setempat, yang tanpa kehadirannya program pembangunan dan proyek akan gagal, (2) Masyarakat mempercayai program pembagunan jika dilibatkan dalam proses persiapan dan perencanaannya, karena masyarakat lebih mengetahui seluk beluk proyek dan merasa memiliki proyek tersebut, (3) Partisipasi merupakan hak demokrasi masyarakat dalam keterlibatannya di pembangunan. (http://bagasaskara.wordpress.com). Dengan demikian partisipasi yang dimaksud dalam kajian ini adalah bahwa ;

- Pemerintahan daerah memberikan kesempatan yang lebih luas dan leluasa kepada masyarakat Papua untuk berpartisipasi dalam pengambilan keputusan publik menyangkut kebutuhan mereka sendiri.

- Jika semakin besar partisipasi publik (masyarakat Papua) dalam pengambilan keputusan, maka hasilnya akan lebih relevan dengan kebutuhan publik, bahkan dukungan publik terhadap keputusan yang diambil akan semakin kuat.

\section{Transparansi}

Transparansi adalah memberikan informasi keuangan yang terbuka dan jujur kepada masyarakat berdasarkan pertimbangan bahwa masyarakat memiliki hak untuk mengetahui secara terbuka dan menyeluruh atas pertanggungjawaban pemerintah dalam pengelolaan sumber daya yang dipercayakan kepadanya dan ketaatannya pada peraturan perundang- undangan (KK, SAP,2005). 
Penyelengaraan pemerintahan yang transparan akan memiliki kriteria sebagai berikut : (1) Adanya pertanggungjawaban terbuka; (2) Adanya aksesibilitas terhadap laporan keuangan; (3) Adanya publikasi laporan keuangan, hak untuk tahu hasil audit dan ketersediaan informasi kinerja.

Dalam ranah keuangan public, UU No. 17 Tahun 2003 menuntut adanya transparansi dan akuntabilitas dalam keuangan publik. Laporan keuangan memang merupakan salah satu hasil dari transparansi dan akuntabilitas keuangan publik. Ini berarti laporan keuangan yang disusun pun harus memenuhi syarat akuntabilitas dan transparansi. Dari konsep dan pengertian di atas, maka dapat simpulkan bahwa yang dimaksud "Transparansi" dalam kajian ini adalah suatu upaya pemerintah daerah yang secara sengaja menyediakan semua informasi menyangkut dana Otsus Papua yang mampu dirilis secara legal baik positif maupun negatif secara akurat, tepat waktu, seimbang, dan tegas, dengan tujuan untuk meningkatkan kemampuan penalaran publik dan mempertahankan tanggung jawab organisasi atas tindakan, kebijakan, dan praktiknya.

\section{Akuntabilitas}

Semakin meningkatnya tuntutan masyarakat terhadap penyelenggaraan pemerintahan yang baik dan bersih (good governance dan clean government) telah mendorong pengembangan dan penerapan sistem pertanggungjawaban yang jelas, tepat, teratur, dan efektif yang dikenal dengan "Sistem Akuntabilitas Kinerja Instansi Pemerintah (SAKIP)".

Penerapan sistem tersebut bertujuan agar penyelenggaraan pemerintahan dan pembangunan dapat berlangsung secara berdaya guna, berhasil guna, bertanggung jawab dan bebas dari praktik-praktik kolusi, korupsi, dan nepotisme (KKN). Terdapat berbagai definisi tentang akuntabilitas, dapat diuraikan sebagai berikut: (1). Sjahruddin Rasul, menyatakan bahwa akuntabilitas didefinisikan secara sempit sebagai 
kemampuan untuk memberi jawaban kepada otoritas yang lebih tinggi atas tindakan "seseorang" atau "sekelompok orang" terhadap masyarakat secara luas atau dalam suatu organisasi. Dalam konteks institusi pemerintah, "seseorang" tersebut adalah pimpinan instansi pemerintah sebagai penerima amanat yang harus memberikan pertanggungjawaban atas pelaksanaan amanat tersebut kepada masyarakat atau publik sebagai pemberi amanat. (2). J.B. Ghartey, menyatakan bahwa akuntabilitas ditujukan untuk mencari jawaban atas pertanyaan yang berhubungan dengan stewardship yaitu apa, mengapa, siapa, ke mana, yang mana, dan bagaimana suatu pertanggungjawaban harus dilaksanakan. (3) Ledvina V. Carino, mengatakan bahwa akuntabilitas merupakan suatu evolusi kegiatan-kegiatan yang dilaksanakan oleh seorang petugas baik yang masih berada pada jalur otoritasnya atau sudah keluar jauh dari tanggung jawab dan kewenangannya. Setiap orang harus benar-benar menyadari bahwa setiap tindakannya bukan hanya akan memberi pengaruh pada dirinya sendiri saja. Akan tetapi, ia harus menyadari bahwa tindakannya juga akan membawa dampak yang tidak kecil pada orang lain. Dengan demikian, dalam setiap tingkah lakunya seorang pejabat pemerintah harus memperhatikan lingkungannya. (4) Akuntabilitas juga dapat berarti sebagai perwujudan pertanggungjawaban seseorang atau unit organisasi, dalam mengelola sumber daya yang telah diberikan dan dikuasai, dalam rangka pencapaian tujuan, melalui suatu media berupa laporan akuntabilitas kinerja secara periodik. Sumber daya dalam hal ini merupakan sarana pendukung yang diberikan kepada seseorang atau unit organisasi dalam rangka memperlancar pelaksanaan tugas yang telah dibebankan kepadanya. Wujud dari sumber daya tersebut pada umumnya berupa sumber daya manusia, dana, sarana prasarana, dan metode kerja. Sedangkan pengertian sumber daya dalam konteks negara dapat berupa aparatur pemerintah, sumber daya alam, peralatan, uang, dan kekuasaan hukum dan politik. (5) Akuntabilitas juga dapat diuraikan sebagai 
kewajiban untuk menjawab dan menjelaskan kinerja dari tindakan seseorang atau badan kepada pihak-pihak yang memiliki hak untuk meminta jawaban keterangan dari orang atau badan yang telah diberikan wewenang untuk mengelola sumber daya tertentu. Dalam konteks ini, pengertian akuntabilitas dilihat dari sudut pandang pengendalian dan tolok ukur pengukuran kinerja. Selanjutnya Akuntabilitas juga dapat diartikan sebagai proses mempertanggungjawabkan pengelolaan sumber daya serta pelaksanaan kebijakan yang dipercayakan kepada entitas pelaporan dalam mencapai tujuan yang telah ditetapkan secara periodik (KK, SAP, 2005). Akuntabilitas merupakan kewajiban menyampaikan pertanggungjawaban atau untuk menjawab atau menerangkan kinerja dan tindakan seseorang/badan hukum/pimpinan kolektif suatu organisasi kepada pihak yang memiliki hak atau berkewenangan untuk minta keterangan akan pertanggungjawaban (LAN, 2003).

Dari berbagai definisi akuntabilitas seperti tersebut di atas, dapat disimpulkan bahwa akuntabilitas merupakan perwujudan kewajiban seseorang atau unit organisasi untuk mempertanggungjawabkan pengelolaan sumber daya dan pelaksanaan kebijakan yang dipercayakan kepadanya dalam rangka pencapaian tujuan yang telah ditetapkan melalui media pertanggungjawaban berupa laporan akuntabilitas kinerja secara periodik. Dengan demikian akuntabilitas merupakan: (1) Salah satu pilar dari konsep tata kelola pemerintahan yang baik (good government governance), (2) Adanya akuntabilitas memungkinkan masyarakat memperoleh informasi yang mereka butuhkan untuk menilai apakah tindakan pemerintah didasarkan pada nilai-nilai penting dari tata pemerintahan yang baik, seperti efektivitas, integritas, demokrasi, dan transparansi. 


\section{Dana Otonomi Khusus}

Sesuai Pasal 34 ayat 3 huruf e, bahwa yang dimaksud dana Otonomi Khusus Papua adalah Penerimaan Khusus dalam rangka Pelaksanaan Otonomi Khusus yang besarnyan setara dengan 2\% (dua persen) dari plafon Dana Aloksi Umum Nasional, yang terutama ditujukkan untuk pembiayaan pendidikan dan kesehatan; dan, huruf $f$, Dana tambahan dalam rangka pelaksanaan Otonomi Khusus yang besarannya ditetapkan antara pemerintah dengan DPR berdasarkan usulan Provinsi pada tiap tahun anggaran, yang terutama ditujukan untuk pembiayaan pembangunan infrastruktur.

Selanjutnya pasal 36 ayat 2 menyatakan bahwa sekurangkurangnya $30 \%$ (tiga puluh persen) penerimaan sebagaian dimaksud dalam pasal 34 ayat 3 dialokasikan untuk biaya pendidikan, dan sekurang-kurangnya 15\% (lima belas persen) untuk kesehatan dan perbaikan gizi.

Dalam mekanisme perencanaan dan penganggaran di Pemda Provinsi Papua, dana Otsus yang diterima dari Pemerintah didistribusikan 40 persen untuk Provinsi Papua dan 60 persen untuk kabupaten/kota. Untuk dana yang dikelola Pemda Provinsi Papua, direncanakan penggunaannya melalui program dan kegiatan pada sejumlah Satuan Kerja Perangkat Daerah (SKPD) dengan ketentuan: (1) tidak boleh dianggarkan bagi belanja aparatur-kecuali bagi aparatur yang langsung memberi pelayanan kepada warga, (2) dialokasikan untuk bidang pendidikan minimal 30 persen, bidang kesehatan minimal 15 persen, bidang infrastruktur, dan bidang perekonomian rakyat.

Dana yang diafektasikan bagi daerah kabupaten dan kota direncanakan oleh masing-masing pemda dalam APBD. Untuk menjaga agar dana dialokasikan sesuai ketentuan dan kebijakan Otsus Papua, Bappeda Provinsi Papua memberi arahkan melalui mekanisme usulan perencanaan dari kabupaten/kota yang dikenal sebagai Usulan Rencana 
Definitif (URD). Setiap Pemda yang telah menerima alokasi anggaran dari sumber Otsus menyusun daftar rencana penggunaan dana yang disusun oleh Bappeda kabupaten/kota kemudian dibahas bersama di Bappeda Provinsi Papua. Daftar rencana penggunaan dana Otsus setelah dibahas dan mendapat persetujuan Bappeda Provinsi dibawa kembali ke daerah masing-masing untuk dijabarkan dalam APBD.

Sejak tahun 2006, dana Otsus juga dialokasikan ke kampung dan distrik melalui program Rencana Stratejik Pembangunan Kampung (RESPEK). Dana ini dialokasikan Pemerintah Provinsi Papua dalam bentuk Block Grants. Bantuan diberikan dalam bentuk tunai untuk direncanakan penggunaannya secara partisipatif oleh warga kampung. Beberapa prinsip good governance seperti transparansi, akuntabilitas, partisipatif, dan pengawasan warga menjadi panduan utama dan diatur dalam program RESPEK. Warga kampung merencanakan, melaksanakan, dan mengawasi sendiri setiap program dan kegiatan. Walau disain program RESPEK ini dinilai positif untuk meningkatkan pembangunan dari bawah (bottom up planning) sejumlah kelemahan masih perlu diidentifikasi dan diselesaikan.

Dana Otsus yang dialirkan ke Provinsi Papua telah dialokasikan untuk berbagai kebutuhan dan tuntutan pembangunan pelayanan publik di Papua. Banyak program pembangunan yang telah dilaksanakan Pemda Provinsi Papua, Pemda Kabupaten dan Kota, dan warga kampung melalui RESPEK (Bappeda, 2007). Hasil-hasil pembangunan senyatanya sudah terlihat di berbagai sudut-sudut kota dan pelosok kampung. Pembangunan prasarana dan sarana pelayanan pendidikan serta kesehatan terus dibangun. Prasarana jalan dan jembatan dibangun dan dipelihara, menggunakan dana Otsus, sehingga jalan-jalan tembus untuk menghubungkan pusat pemerintahan dengan kampung-kampung Papua, yang semula terisolasi akhirnya dapat ditembus dan dilalui kendaraan roda empat, sehingga penduduk kampung sudah mulai 
mendapatkan pelayanan dasar dan menjual hasil pertanian ke pasarpasar lokal.

Pelayanan dasar untuk pendidikan dan kesehatan merupakan bidang dan urusan pemerintahan yang selalu mendapat perhatian. Sebagai contoh dalam APBD Provinsi Papua TA 2011, pelayanan dasar mendapat alokasi belanja masing-masing Rp263 milyar untuk bidang pendidikan dan Rp475 milyar untuk bidang kesehatan. Bila nilai tersebut dihitung dalam persentase setelah alokasi dana Otsus ke kabupaten/kota-pendidikan mendapat alokasi 13 persen dan kesehatan memperoleh alokasi 24 persen. Dalam APBD kabupaten/kota untuk TA 2011 pelayanan dasar secara rata-rata memperoleh plafon anggaran masing-masing Rp112 milyar (17 persen) untuk pendidikan dan Rp55 milyar (19 persen) untuk kesehatan. Pada TA 2011, total APBD yang dialokasi Provinsi Papua dan 29 kabupaten/kota untuk bidang pendidikan Rp3,51 trilyun (17 persen), dan bidang kesehatan Rp2,07 trilyun (10 persen).

\section{Kondisi Umum Sosial Ekonomi Kabupaten Asmat}

\section{(1) Pembangunan Ekonomi Daerah}

Produk Domestik Regional Bruto (PDRB) Kabupaten Asmat mengalami peningkatan dalam kurun waktu 2008-2012. PDRB Asmat atas dasar harga berlaku tahun 2008 bernilai Rp464 milyar dan meningkat hingga mencapai Rp866 milyar pada tahun 2012 atau dengan pertumbuhan rata-rata sebesar 16,91 persen. PDRB atas dasar harga konstan juga mengalami hal yang sama, pada tahun 2008 tercatat sebesar Rp210 milyar dan mencapai Rp295 milyar pada tahun 2012 dengan pertumbuhan rata-rata sebesar 8,88 persen. 
Tabel 2

PDRB Kabupaten Asmat Tahun 2008-2012 (juta rupiah)

\begin{tabular}{|c|c|c|c|c|}
\hline \multirow{2}{*}{ Tahun } & \multicolumn{2}{|c|}{ PDRB ADHB } & \multicolumn{2}{c|}{ PDRB ADHK } \\
\cline { 2 - 5 } & Nilai & \% & Nilai & $\%$ \\
\hline $\mathbf{2 0 0 8}$ & $464.149,55$ & & $210.549,30$ & \\
\hline $\mathbf{2 0 0 9}$ & $521.394,18$ & 12,33 & $218.939,86$ & 3,99 \\
\hline $\mathbf{2 0 1 0}$ & $619.893,54$ & 18,89 & $241.466,31$ & 10,29 \\
\hline $\mathbf{2 0 1 1}$ & $730.130,57$ & 17,78 & $266.751,85$ & 10,47 \\
\hline $\mathbf{2 0 1 2}$ & $866.083,41$ & 18,62 & $295.533,53$ & 10,79 \\
\hline
\end{tabular}

Sumber: PDRB Kabupaten Asmat, 2012

Sektor pertanian memberikan kontribusi tertinggi dalam pembentukan nilai PDRB Kabupaten Asmat dalam kurun waktu 20082012. Sektor pertanian memberikan kontribusi rata-rata sebesar 39,35 persen. Di urutan kedua terdapat sektor jasa-jasa yang menyumbang rata-rata sebesar 35,47 persen. Di posisi ketiga diikuti oleh sektor bangunan dengan kontribusi rata-rata sebesar 12,90 persen.

Tabel 3

Struktur Perekonomian Kabupaten Asmat Tahun 2008-2012 (persen)

\begin{tabular}{|c|c|c|c|c|c|c|}
\hline $\begin{array}{c}\text { Sektor Ekonomi (Lapangan } \\
\text { Usaha) }\end{array}$ & 2008 & 2009 & 2010 & 2011 & 2012 & $\begin{array}{l}\text { Rata- } \\
\text { Rata }\end{array}$ \\
\hline Pertanian & 42,81 & 42,50 & 39,75 & 37,22 & 34,47 & 39,35 \\
\hline Pertambangan dan Penggalian & 0,11 & 0,11 & 0,11 & 0,09 & 0,08 & 0,10 \\
\hline Industri Pengolahan & 1,20 & 1,25 & 1,24 & 1,21 & 1,12 & 1,20 \\
\hline Listrik dan Air Bersih & 0,00 & 0,00 & 0,00 & 0,01 & 0,01 & 0,00 \\
\hline Bangunan & 11,82 & 12,99 & 13,38 & 13,11 & 13,22 & 12,90 \\
\hline Perdagangan, Hotel, dan Restoran & 5,80 & 6,13 & 6,11 & 6,07 & 6,16 & 6,06 \\
\hline Pengangkutan dan Komunikasi & 2,94 & 3,25 & 3,29 & 3,32 & 3,25 & 3,21 \\
\hline $\begin{array}{l}\text { Keuangan, Persewaan, dan Jasa } \\
\text { Perusahaan }\end{array}$ & 1,66 & 1,74 & 1,74 & 1,71 & 1,69 & 1,71 \\
\hline Jasa-Jasa & 33,66 & 32,01 & 34,38 & 37,27 & 40,00 & 35,47 \\
\hline
\end{tabular}

Sumber: PDRB Kabupaten Asmat, 2012

Kontribusi di sektor pertanian bagi perkonomian yang cukup besar dapat memperlihatkan bahwa meskipun dengan kondisi tanah di 
Kabupaten Asmat yang berlumpur tapi dapat menghasilkan produksi tanaman pangan yang baik. Kondisi sebaliknya di sektor listrik dan air bersih, dari angka yang diperoleh menunjukkan kontribusi sektor ini sama sekali tidak ada.

Laju pertumbuhan ekonomi Kabupaten Asmat selama kurun waktu empat tahun terakhir berfluktuasi ringan dengan kecenderungan menurun. Setiap tahun pertumbuhan ekonomi rata-rata mencapai 10,29 persen, namun di tahun 2009 pertumbuhan ekonomi hanya mencapai 8,89 persen. Selain itu laju pertumbuhan rata-rata untuk sektor ekonomi Kabupaten Asmat sangat variatif. Sektor listrik dan air bersih mengalami pertumbuhan paling tinggi yaitu sebesar 22,78 persen, disusul sektor jasa-jasa sebesar 14 persen, sektor bangunan sebesar 11,97 persen.

Tabel 4

Pertumbuhan Rata-Rata Sektor Ekonomi di Kabupaten Asmat Tahun 2009-2012 (persen)

\begin{tabular}{|c|c|c|c|c|c|}
\hline $\begin{array}{c}\text { Sektor Ekonomi (Lapangan } \\
\text { Usaha) }\end{array}$ & 2009 & 2010 & 2011 & 2012 & $\begin{array}{l}\text { Rata- } \\
\text { Rata }\end{array}$ \\
\hline Pertanian & 3,24 & 3,14 & 3,44 & 2,62 & 3,11 \\
\hline \multicolumn{6}{|l|}{ Pertambangan dan } \\
\hline Penggalian & 8,67 & 6,47 & $-4,74$ & $-1,47$ & 2,23 \\
\hline Industri Pengolahan & 8,32 & 8,88 & 7,87 & 3,27 & 7,09 \\
\hline Listrik dan Air Bersih & 12,34 & 10,45 & 34,85 & 33,50 & 22,78 \\
\hline Bangunan & 14,35 & 13,57 & 8,22 & 11,73 & 11,97 \\
\hline \multicolumn{6}{|l|}{ Perdagangan, Hotel, dan } \\
\hline Restoran & 9,90 & 9,99 & 9,70 & 12,38 & 10,49 \\
\hline \multicolumn{6}{|l|}{ Pengangkutan dan } \\
\hline Komunikasi & 14,96 & 11,53 & 11,51 & 8,43 & 11,61 \\
\hline \multicolumn{6}{|l|}{ Keuangan, Persewaan, dan } \\
\hline Jasa Perusahaan & 9,32 & 10,02 & 8,62 & 9,26 & 9,31 \\
\hline Jasa-Jasa & $-1,12$ & 18,47 & 19,75 & 18,91 & 14,00 \\
\hline
\end{tabular}

Sumber: PDRB Kabupaten Asmat, 2012 


\section{(2) Kualitas Pembangunan Manusia}

Jumlah penduduk Asmat berfluktuasi untuk kurun waktu 2008-2012. Pada tahun 2009 penduduk Asmat berjumlah 77 ribu jiwa turun menjadi 76 ribu jiwa pada tahun 2010, namun meningkat terus hingga mencapai 81 ribu jiwa pada tahun 2012. Penduduk laki-laki lebih banyak dibanding penduduk perempuan hal ini menyebabkan sex ratio mengalami peningkatan selama kurun waktu tersebut. Rata-rata pertumbuhan penduduk Asmat selama lima tahun terakhir sebesar 1,79 persen. Jumlah penduduk Kabupaten Asmat yang masuk dalam usia produktif (15-54 tahun) cukup banyak yaitu sebesar 43.379 jiwa atau 52,84 persen dari total penduduk Kabupaten Asmat, sedangkan usia antara 0-14 tahun mencapai 36.486 jiwa atau 44,44 persen. Kondisi tersebut memperlihatkan bahwa jumlah penduduk yang berpotensi untuk masuk dalam usia produktif cukup banyak. IPM Kabupaten Asmat dalam kurun waktu 2008-2011 lebih jelek dibanding Provinsi Papua. Secara rata-rata IPM Asmat sebesar 51,15 sedangkan IPM Provinsi Papua sebesar 64,71. Ada tiga komponen IPM yang lebih rendah di Kabupaten Asmat dibanding dengan Provinsi Papua, yaitu angka harapan hidup, rata-rata lama sekolah, dan angka melek huruf.

\section{(3) Kemiskinan dan Ketimpangan Pendapatan}

Jumlah penduduk miskin di Kabupaten Asmat cenderung stabil. Antara tahun 2007 sampai dengan 2010 jumlah penduduk miskin cenderung sama dengan rata-rata 14.841 jiwa atau 19,31 persen dari total jumlah penduduk. Namun, pada tahun 2011 jumlah penduduk miskin meningkat sebanyak 3.410 jiwa atau 2,85 persen dari total jumlah penduduk, hal ini memperlihatkan bahwa kontribusi dana Otsus belum konsisten dalam menanggulangi kemiskinan. 


\section{Gambar 2}

Perkembangan Tingkat Kemiskinan di Kabupaten Asmat Tahun 2007-2011

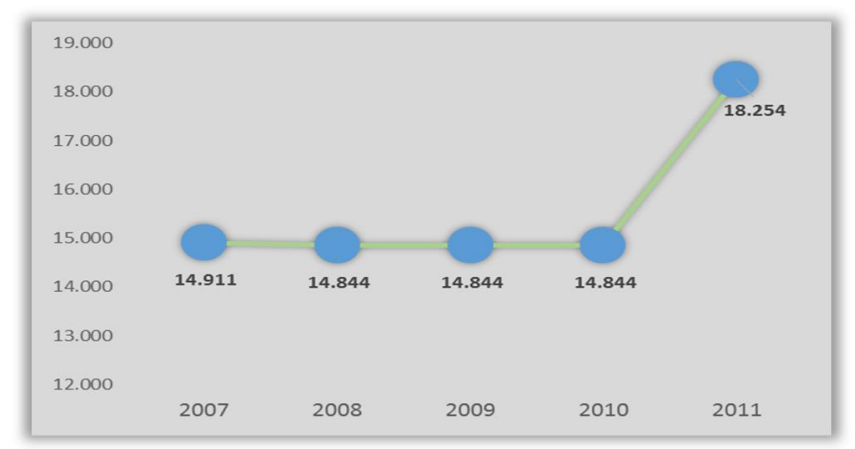

Sumber: Kabupaten Asmat Dalam Angka Tahun 2012

\section{Komposisi Dana Otsus}

Dana Otsus yang diterima Kabupaten Asmat perioda tahun anggaran 2009 sampai dengan 2012 berjumlah Rp246 milyar. Besaran dana yang diterima juga sangat berfluktuatif, misalnya dana Otsus untuk bidang pendidikan dari tahun 2009 dana yang dialokasikan sebesar Rp14 milyar dan pada tahun 2012 meningkat sebesar Rp18 milyar. Selain dana yang dialokasikan meningkat, ada juga sektor atau bidang yang mengalami penurunan alokasi dana, misalnya sektor infrastruktur yang pada tahun 2009 dana yang dialokasikan sebesar Rp25 milyar dan pada tahun 2012 menurun tajam sehingga dana yang dialokasikan hanya sebesar Rp10 milyar. Tetapi secara keseluruhan dana Otsus yang diterima oleh Kabupaten Asmat setiap tahunnya mengalami peningkatan sebesar rata-rata 2,19 persen.

Tabel 5

Jumlah Dana Otonomi Khusus di Kabupaten Asmat Tahun 2009-2012

\begin{tabular}{|l|c|c|c|cc|}
\hline \multicolumn{1}{|c}{ Sektor/Bidang } & $\mathbf{2 0 0 9}$ & $\mathbf{2 0 1 0}$ & $\mathbf{2 0 1 1}$ & $\mathbf{2 0 1 2}$ & Total 4 tahun \\
\hline Pendidikan & 14.904 .334 .703 & 14.937 .012 .750 & 17.924 .415 .300 & 18.949 .653 .800 & 66.715 .416 .553 \\
\hline Kesehatan & 8.962 .160 .822 & 8.962 .207 .650 & 8.962 .207 .650 & 9.474 .826 .500 & 36.361 .402 .622 \\
\hline Infrastruktur & 25.424 .224 .853 & 20.911 .817 .850 & 16.286 .817 .850 & 10.941 .030 .500 & 73.563 .891 .053 \\
\hline Ekonomi Kerakyatan & 10.424 .730 .622 & 14.937 .012 .750 & 19.992 .069 .200 & 24.299 .999 .200 & 69.653 .811 .772 \\
\hline Total Dana Otsus & $\mathbf{5 9 . 7 1 5 . 4 5 3 . 0 0 9}$ & $\mathbf{5 9 . 7 4 8 . 0 5 3 . 0 1 0}$ & $\mathbf{6 3 . 1 6 5 . 5 1 2 . 0 1 1}$ & $\mathbf{6 3 . 6 6 5 . 5 1 2 . 0 1 2}$ & $\mathbf{2 4 6 . 2 9 4 . 5 3 0 . 0 4 2}$ \\
\hline
\end{tabular}

Sumber: Rencana Definitif Otsus Kabupaten Asmat Tahun 2009-2012 
Proporsi dana Otsus terhadap total pendapatan Kabupaten Asmat pada tahun 2009 sampai dengan 2012 berfluktuatif. Pada tahun anggaran 2009 proporsi dana Otsus terhadap total pendapatan sebesar 4,10 persen, lalu pada tahun 2011 menurun sebesar 3,87 persen, namun pada tahun 2012 proporsi dana Otsus naik sebesar 7,43 persen. Hal ini terjadi bisa disebabkan dari total pendapatan yang diterima oleh Kabupaten Asmat secara keseluruhan.

\section{Gambar 3}

Proporsi Dana Otsus Terhadap Total Pendapatan di Kabupaten Asmat Tahun 2007-2011

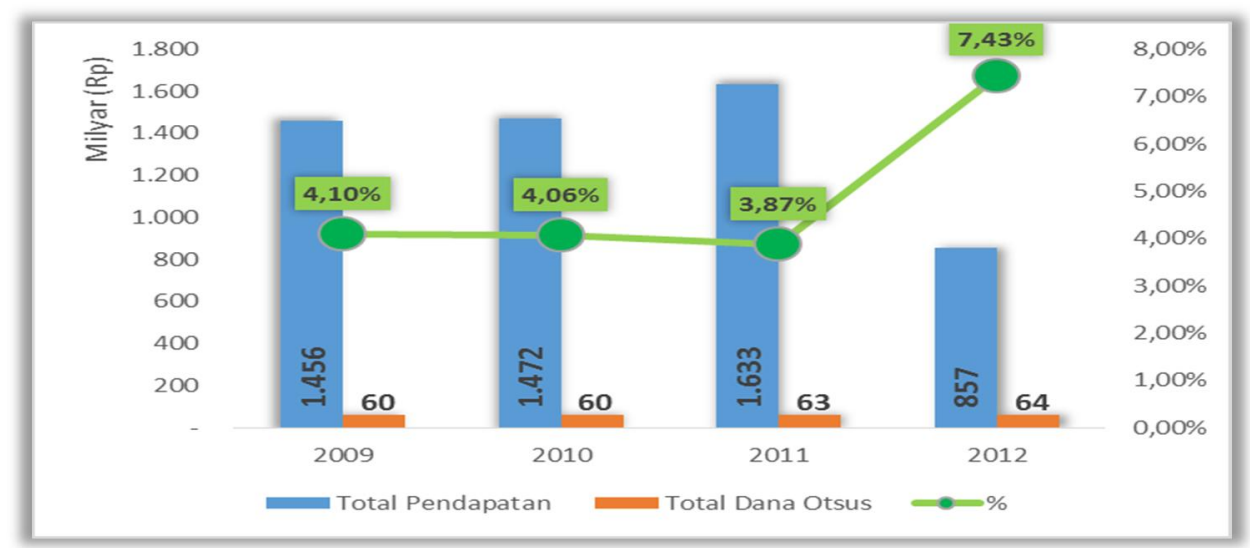

Sumber: Rencana Definitif Otsus Kabupaten Asmat Tahun 2009-2012 (data diolah)

Peruntukan dana Otsus di Kabupaten Asmat selama tahun 2009 sampai dengan 2012 bergerak berfluktuasi, dapat terlihat di gambar bawah ini, yaitu bidang infrastruktur setiap tahun mengalami penurunan dan ekonomi kerakyatan yang mengalami peningkatan setiap tahun hal yang sama juga di bidang pendidikan meskipun peningkatannya tidak terlalu signifikan. 
Gambar 4

Jumlah dan Proporsi Penggunaan Dana Otsus Per Bidang di Kabupaten Asmat Tahun 2007-2011

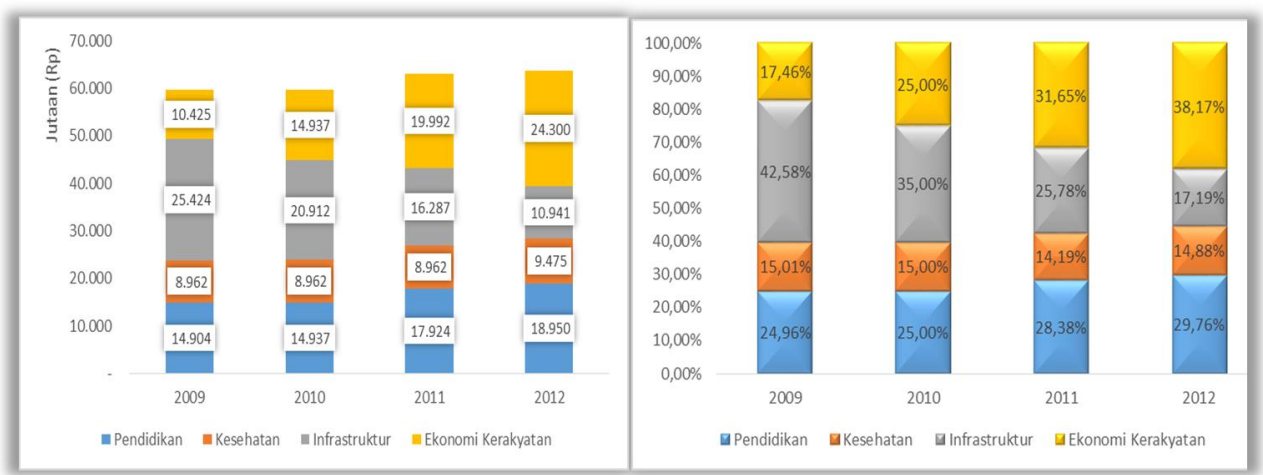

Sumber: Rencana Definitif Otsus Kabupaten Asmat Tahun 2009-2012 (data diolah)

Bila dihitung penerimaan dana Otsus antara tahun 2009 sampai dengan 2012 dan peruntukan untuk beberapa bidang prioritas yang diamanatkan oleh UU Otsus, maka bidang pendidikan belum memenuhi amanat Otsus, karena belum mencapai 30 persen peruntukan dana untuk bidang pendidikan. Sedangkan bidang kesehatan sudah memenuhi amanat UU Otsus, yaitu sebesar 15 persen.

\section{Gambar 5}

Jumlah dan Proporsi Penggunaan Dana Otsus Per Bidang di Kabupaten Asmat Tahun 2007-2011

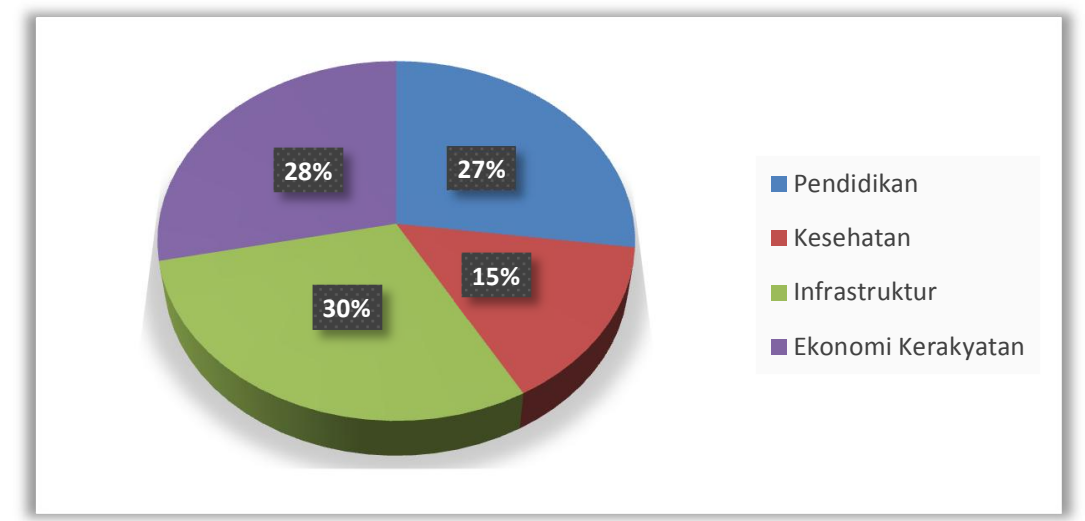

Sumber: Rencana Definitif Otsus Kabupaten Asmat Tahun 20092012 (data diolah) 
Dana Otsus yang digulirkan oleh pemerintah pusat pada Provinsi Papua tidak dialokasikan secara langsung ke tangan masyarakat namun biasanya direalisir dalam bentuk program dan kegiatan. Apabila dana Otsus yang diterima oleh Pemda Kabupaten Asmat setiap tahunnya dibagi kepada setiap penduduk asli orang Papua maka besarnya dana Otsus perkapita terlihat dalam tabel berikut.

Tabel 6

Dana Otonomi Khusus Per Kapita Kabupaten Asmat Menurut Jumlah Penduduk Tahun 2009-2012

\begin{tabular}{|c|c|c|c|}
\hline Tahun & $\begin{array}{c}\text { Dana Otsus } \\
\text { (Rp) }\end{array}$ & $\begin{array}{c}\text { Jumlah Penduduk } \\
\text { (Jiwa) }\end{array}$ & $\begin{array}{c}\text { Dana Otsus } \\
\text { Per Kapita (Rp) }\end{array}$ \\
\hline $\mathbf{2 0 0 9}$ & 59.715 .453 .009 & 77.026 & $775.263,59$ \\
\hline $\mathbf{2 0 1 0}$ & 59.748 .053 .010 & 76.563 & $780.377,64$ \\
\hline $\mathbf{2 0 1 1}$ & 63.165 .512 .011 & 82.097 & $769.400,98$ \\
\hline $\mathbf{2 0 1 2}$ & 63.665 .512 .012 & 81.696 & $779.297,79$ \\
\hline
\end{tabular}

Sumber: Rencana Definitif Otsus Asmat dan Kabupaten Asmat Dalam Angka 2009-2012

Total dana Otsus perkapita di Kabupaten Asmat berfluktuasi selama tahun 2009 s/d 2012. Perkapita tertinggi berada pada tahun 2010 dan yang terendah berada pada tahun 2009, namun selisih setiap tahun tidak terlalu besar, hal ini menunjukkan bahwa dana Otsus yang dialokasikan selama empat tahun terakhir dapat mencukupi kebutuhan penduduk Kabupaten Asmat secara keseluruhan.

\section{Otsus Sektor Pendidikan}

Alokasi dana Otsus untuk sektor pendidikan belum sesuai dengan ketentuan. Sesuai dengan amanat UU Otsus tentang Peruntukan dana Otsus untuk sektor pendidikan yaitu 30 persen, alokasi dana Otsus di bidang pendidikan rata-rata mencapai 27,03 persen selama empat tahun anggaran. Hal ini menunjukkan komitmen yang belum maksimal dari pemerintah Kabupaten Asmat untuk meningkatkan kualitas dan kuantitas 
pendidikan. Namun bila dilihat tren selama empat tahun pengamatan terdapat peningkatan alokasi setiap tahun sebesar 8,65 persen.

\section{Gambar 6}

Alokasi Dana Otsus Bidang Pendidikan di Kabupaten Asmat Tahun 2009-2012

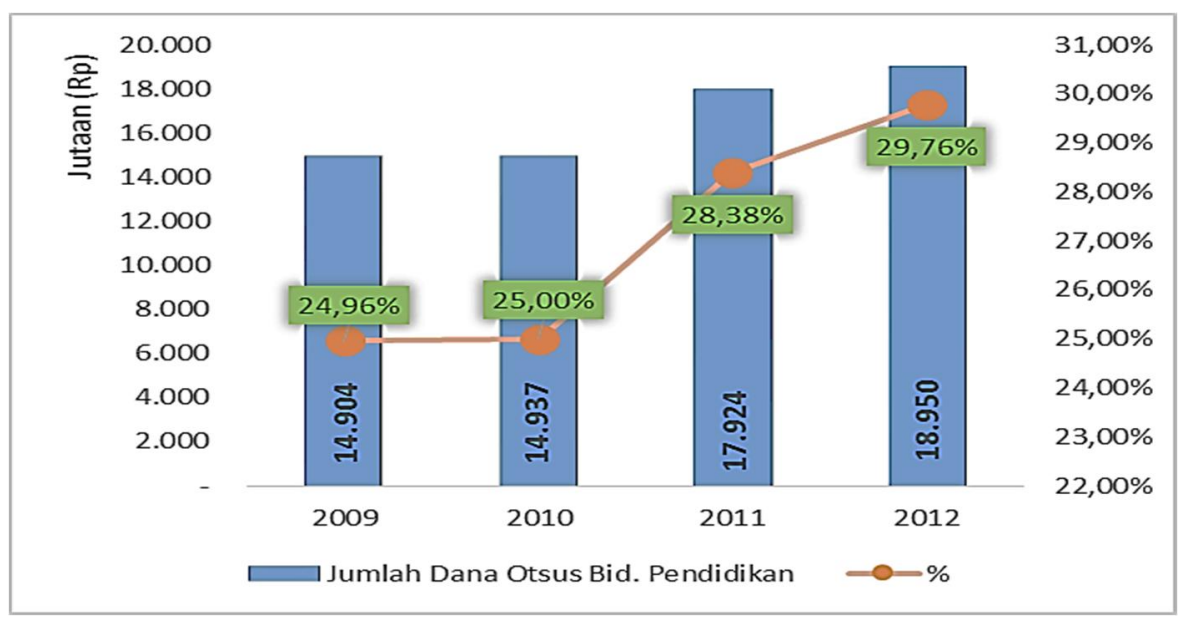

Sumber: Rencana Definitif Otsus Kabupaten Asmat Tahun 2009-2012 (data diolah)

\section{Otsus Sektor Kesehatan}

Alokasi dana Otsus untuk sektor kesehatan telah sesuai dengan ketentuan dan amanat UU Otsus. Sesuai dengan Keputusan Gubernur Provinsi Papua tentang Peruntukan dana Otsus untuk sektor kesehatan yaitu 15 persen selama lima tahun pengamatan. Pertumbuhan alokasi dana Otsus untuk kesehatan selama empat tahun rata-rata 1,91 persen, hal ini memperlihatkan komitmen yang baik dari Pemerintah kabupaten Asmat untuk memperbaiki pelayanan kesehatan, meskipun pada tahun 2011 dan 2012 mengalami penurunan alokasi dana. 


\section{Gambar 7}

Alokasi Dana Otsus Bidang Kesehatan

di Kabupaten Asmat Tahun 2009-2012

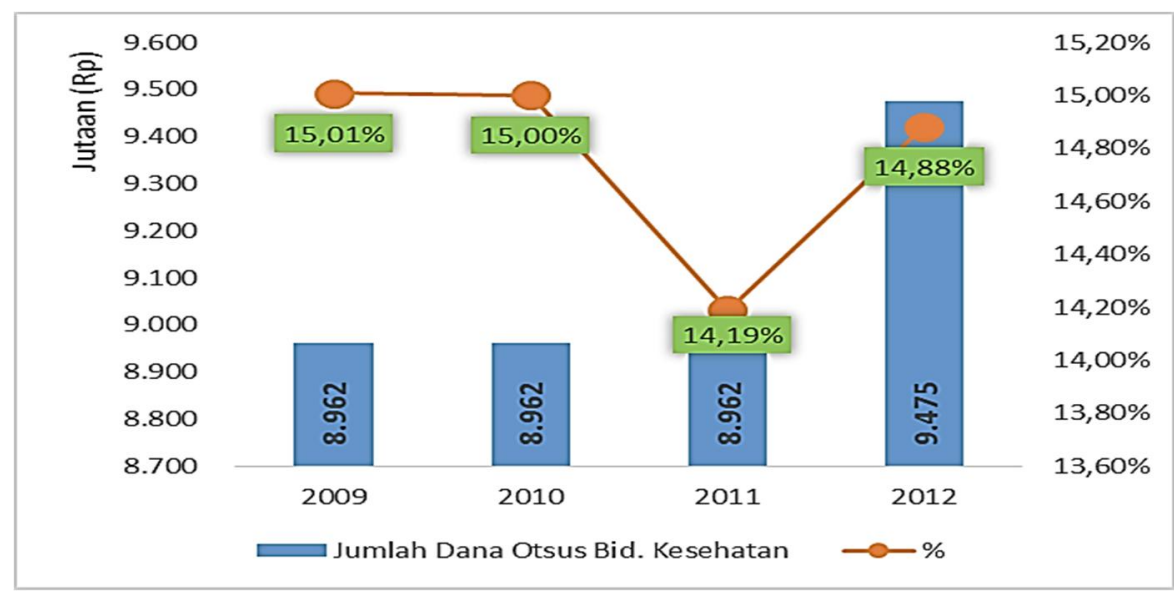

Sumber: Rencana Definitif Otsus Kabupaten Asmat Tahun 2009-2012 (data diolah)

\section{Kinerja Output Pengelolaan Dana Otsus Kabupaten Asmat}

\section{(1) Partisipasi}

Penerapan sistem pemerintahan yang terdesentralisasi memberikan kesempatan yang lebih luas kepada masyarakat untuk berpartisipasi dalam pengambilan keputusan. Masyarakat mendapatkan kembali kesetaraan politik dalam menjalankan roda pemerintahannya. Desentralisasi politik bertujuan untuk memberikan lebih banyak kesempatan dan kekuasaan kepada para warga negara di dalam pengambilan keputusan publik. Desentralisasi politik ini identik dengan demokratisasi, yaitu dengan asumsi bahwa semakin besar partisipasi publik dalam pengambilan keputusan, maka hasilnya akan lebih relevan dengan kebutuhan publik, bahkan dukungan publik terhadap keputusan yang diambil akan semakin kuat.

Partisipasi sangat penting karena mengandung aspek dasar kemanusiaan. Semua orang ingin dihargai melalui peran dan partisipasi mereka dan semua orang ingin berperan dalam kegiatan apa pun yang secara langsung mempengaruhi kehidupan mereka. Dalam era Otonomi 
Khusus di Tanah Papua, Pemerintah Provinsi Papua melakukan kebijakan kependudukan dalam bentuk kebijakan afirmatif untuk mempercepat partisipasi penduduk asli Papua di semua sektor pembangunan, termasuk dalam bentuk orang-orang asli Papua memperoleh kesempatan dan diutamakan untuk memperoleh pekerjaan dalam semua bidang pekerjaan (Pasal 61 dan 62, UU 21/2001).

Partisipasi masyarakat Papua khususnya di Kabupaten Asmat di dalam tahap perencanaan dan manajemen pembangunan diupayakan lebih terlembaga, sehingga rencana dan program pembangunan dapat disesuaikan dengan kebutuhan-kebutuhan daerah dan kelompok yang beraneka ragam, yang pada akhirnya memungkinkan terumuskannya program-program yang lebih realistis dan efektif. Hasil pengolahan data kuesioner tentang pendapat masyarakat, lembaga kesehatan, dan beberapa lembaga pemerintah di Kabupaten Asmat terhadap Partisipasi masyarakat yang sebesar-besarnya dilaksanakan dalam perencanaan, pelaksanaan dan pengawasan dalam penyelenggaraan pemerintahan serta pelaksanaan pembangunan melalui keikutsertaan para wakil adat, agama, pemuda, kelompok usaha lokal dan kaum perempuan dapat dilihat pada pembahasan berikut ini.

\section{Gambar 8}

Web Capaian Skor Tingkat Partisipasi Pengelolaan Dana Otsus di Kabupaten Asmat

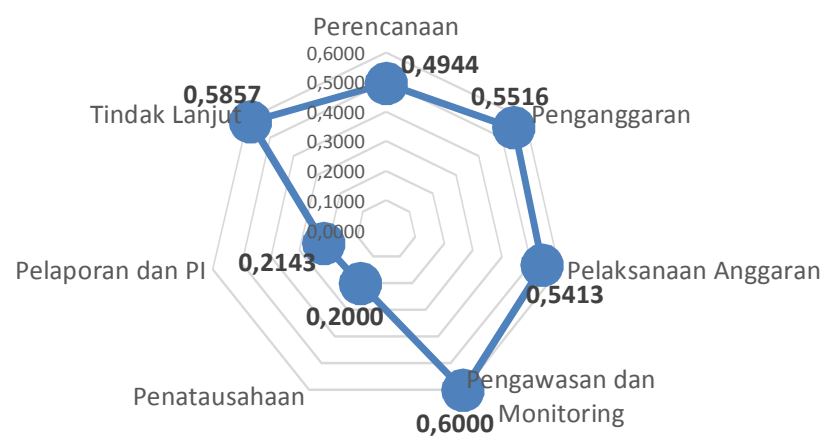

Sumber: Data Primer (diolah, 2013) 
Berdasarkan gambar web capaian skor tingkat partisipasi pengelolaan dana otsus di atas, terlihat skor tertinggi adalah di fokus Pengawasan dan Monitoring dengan capaian sebesar 0,6000 atau 60 persen. Hal ini terjadi karena dalam proses penggunaan anggaran partisipasi masyarakat Asmat dalam bentuk pengawasan dan monitoring cukup bagus dalam mengawal penggunaan anggaran agar dana Otsus yang dipakai tepat sasaran. Pertanyaan yang diangkat dalam aspek ini adalah apakah masyarakat menilai OAP sudah aktif berpartisipasi dalam memonitor kegiatan yang bersumber dari dana Otsus. Hasil survei memperlihatkan bahwa tingkat capaian skor dari SKPD terkait partisipasi, apakah semua pejabat diberi kesempatan mengawasi dan menindak lanjuti hasil monitoring. Dari hasil survei terlihat tingkat partisipasi pejabat dalam pengawasan penggunaan dana Otsus sangat bagus, karena hal itu memperlihatkan salah satu bentuk komitmen dari para pejabat SKPD untuk turut menjamin tingkat efisiensi pengelolaan dana Otsus, hal ini dapat ditunjukkan dari skor tingkat capaian sebesar 1,0000 atau 100 persen. Selain itu senada dengan opini SKPD, tingkat partisipasi masyarakat dalam kegiatan pengawasan dan monitoring sudah baik. Meskipun tingkat capaian skor baik, masih terdapat beberapa kritik terhadap proses pengawasan yaitu seperti kadang-kadang pelaksanaan pengawasan macet disebabkan karena anggota masyarakat yang dilibatkan tidak kompak ataupun hanya terbatas pada kelompok atau personal-personal tertentu saja yang melakukan pengawasan dan monitoring.

Tabel 7

Skor Capaian Tingkat Partisipasi Pengelolaan Dana Otsus Kabupaten Asmat

\begin{tabular}{|l|c|c|c|}
\hline \multicolumn{1}{|c|}{ Fokus Pengelolaan } & SKPD & L P \& K* & Individu \\
\hline Perencanaan & 1,0000 & 0,2000 & 0,2833 \\
\hline Penganggaran & 0,5714 & 0,4000 & 0,6833 \\
\hline Pelaksanaan Anggaran & 0,8571 & 0,0000 & 0,7667 \\
\hline Pengawasan dan Monitoring & 1,0000 & 0,2000 & 0,6000 \\
\hline
\end{tabular}




\begin{tabular}{|l|c|c|c|}
\hline \multicolumn{1}{|c|}{ Fokus Pengelolaan } & SKPD & L P \& K* & Individu \\
\hline Penatausahaan & - & 0,2000 & - \\
\hline Pelaporan dan PI & 0,4286 & 0,0000 & - \\
\hline Tindak Lanjut & 0,8571 & 0,2000 & 0,7000 \\
\hline Jumlah Skor & 4,7143 & 1,2000 & 3,0333 \\
\hline Maksimum & 6,0000 & 7,0000 & 5,0000 \\
\hline Pencapaian & 0,7857 & 0,1714 & 0,6067 \\
\hline Prestasi & B & E & B \\
\hline
\end{tabular}

Sumber; Data Primer (diolah, 2013)

*Lembaga Pendidikan dan Kesehatan

Sedangkan menurut lembaga pendidikan dan kesehatan, tingkat partisipasi dalam pengawasan dan monitoring tidak baik, hal ini dapat dilihat dari tingkat capaian skor yang hanya mencapai 0,2000 atau 20 persen. Hasil yang berbeda dengan masyarakat dan SKPD ini disebabkan karena terbatasnya akses yang diberikan kepada pihak sekolah untuk mengawasi dan memonitor program/kegiatan yang dilaksanakan oleh Dinas Pendidikan. Selain itu dari pihak puskesmas, jarang sekali terlibat langsung dalam mengawasi dan memonitor penggunaan dana yang bersumber dari dana Otsus dalam menentukan kebutuhan peningkatan jumlah sarana dan prasarana puskesmas seperti penambahan dokter, perawat, fasilitas-fasilitas kesehatan, dan lain-lain.

\section{(2) Transparansi}

Transparansi merupakan upaya yang secara sengaja menyediakan semua informasi yang mampu dirilis secara legal baik positif maupun negatif secara akurat, tepat waktu, seimbang, dan tegas, dengan tujuan untuk meningkatkan kemampuan penalaran publik dan mempertahankan tanggung jawab organisasi atas tindakan, kebijakan, dan praktiknya. 


\section{Gambar 9}

Web Capaian Skor Tingkat Transparansi Pengelolaan Dana Otsus

di Kabupaten Asmat

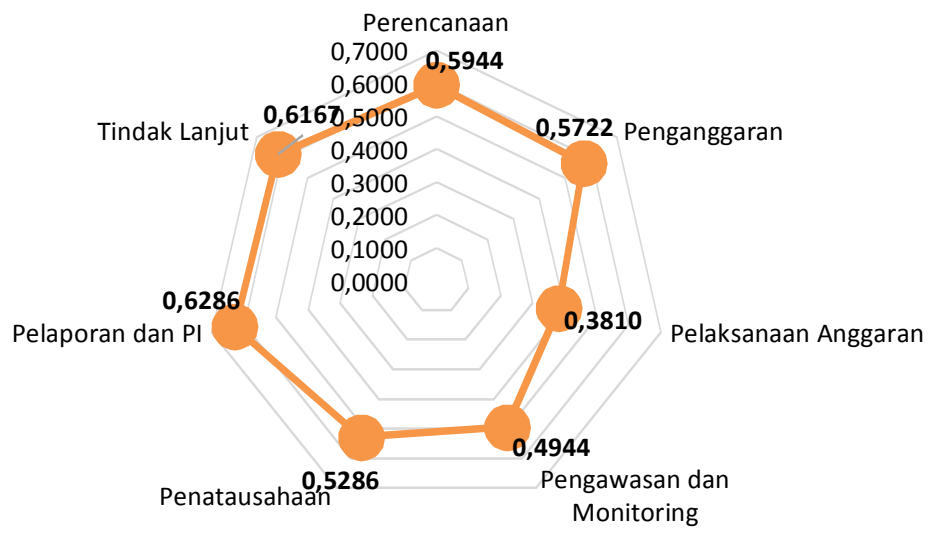

Sumber: Data Primer (diolah, 2013)

Tingkat transparansi pengelolaan dana Otsus di Kabupaten Asmat sudah berjalan dengan baik. Fokus dalam pelaksanaan yang memiliki capaian skor tertinggi adalah fokus Pelaporan dan Pengawasan Internal sebesar 0,6286 atau 62,86 persen. Kegiatan pelaporan dan pengawasan internal merupakan salah bentuk nyata dari aspek transparansi pengelolaan dana Otsus. Dari survei yang dilakukan kepada SKPD, skor capaian tingkat transparansi dalam bentuk prosedur pengaduan/komplain dari masyarakat OAP tentang pelayanan SKPD sebesar 0,8571 atau 85,71 persen, hasil ini menunjukkan tingkat transparansi dalam bentuk rekomendasi dari hasil pengawasan internal telah diketahui oleh pejabat, dan 50 persen lebih pegawai dalam SKPD. Selain itu tingkat capaian pelaporan dan pengawasan internal di lembaga pendidikan dan kesehatan hanya sebesar 0,4000 atau 40 persen, hal ini memperlihatkan bahwa maupun ke sekolah dan puskesmas/rumah sakit cukup baik dalam menerapkan SOP pelayanan pendidikan yang digunakan sekolah maupun di SOP pelayanan kesehatan di rumah sakit/puskesmas, dan selalu dikomunikasikan kepada pegawai dan masyarakat secara terbuka. 
Tabel 8

Skor Capaian Tingkat Transparansi Pengelolaan

Dana Otsus Kabupaten Asmat

\begin{tabular}{|l|c|c|c|}
\hline \multicolumn{1}{|c|}{ Fokus Pengelolaan } & Individu & SKPD & L P\&K \\
\hline Perencanaan & 0,5833 & 1,0000 & 0,2000 \\
\hline Penganggaran & 0,5167 & 1,0000 & 0,2000 \\
\hline Pelaksanaan Anggaran & 0,6000 & 0,1429 & 0,4000 \\
\hline Pengawasan dan Monitoring & 0,2833 & 1,0000 & 0,2000 \\
\hline Penatausahaan & - & 0,8571 & 0,2000 \\
\hline Pelaporan dan PI & - & 0,8571 & 0,4000 \\
\hline Tindak Lanjut & 0,6500 & 1,0000 & 0,2000 \\
\hline Jumlah Skor & 2,6333 & 5,8571 & 1,8000 \\
\hline Maksimum & 5,0000 & 7,0000 & 7,0000 \\
\hline Pencapaian & 0,5267 & 0,8367 & 0,2571 \\
\hline Prestasi & C & A & D \\
\hline
\end{tabular}

Sumber; Data Primer (diolah, 2013)

Namun hal berbeda dalam capaian skor di fokus Pelaksanaan Anggaran yaitu sangat tidak memuaskan. Isu transparansi pada tahap pelaksanaan anggaran melihat isu dalam masyarakat adalah bagaimana penilaian mereka terhadap transparansi pelaksanaan proyek dari sumber dana Otsus sudah bagi pengusaha OAP, dan informasi keuangan RESPEK sudah transparan disampaikan kepada warga. Dari hasil survei terhadap SKPD, capaian skor sangat minimal yaitu sebesar 0,1429 atau 14,29 persen. Hal ini menunjukkan tingkat transparansi di dalam lingkungan SKPD tidak baik, hal ini terjadi karena Kabupaten Asmat belum menggunakan Layanan Pengadaan Secara Elektornik (LPSE), sehingga Kegiatan atau proyek dari sumber Otsus belum dimasukkan dalam LPSE.

Hasil yang sangat berbeda diperoleh dari persepsi masyarakat, tingkat pelaksanaan anggaran yang berasal dari dana Otsus bisa dikatakan baik, hal tersebut dapat terlihat dari capaian skor sebesar 
0,6000 atau 60 persen. Begitu pun dengan persepsi dari pihak lembaga pendidikan dan kesehatan yang mencapai skor sebesar 0,4000 atau 40 persen, meskipun skornya lebih kecil dibandingkan tingkat capaian masyarakat, namun hasil ini memperlihatkan tingkat transparansi dalam pelaksanaan anggaran, cukup baik.

\section{(3) Akuntabilitas}

Akuntabilitas merupakan salah satu pilar dari konsep tata kelola pemerintahan yang baik (good government governance). Adanya akuntabilitas memungkinkan masyarakat memperoleh informasi yang mereka butuhkan untuk menilai apakah tindakan pemerintah didasarkan pada nilai-nilai penting dari tata pemerintahan yang baik, seperti efektivitas, integritas, demokrasi, dan transparansi.

Akuntabilitas dapat menjembatani kesenjangan informasi antara pemerintah daerah dengan publik. Kesenjangan informasi yang sedikit akan memperbaiki komunikasi antara pemerintah daerah dan publik sehingga menghasilkan hubungan yang baik serta mendorong untuk terciptanya rasa percaya publik kepada pemerintah daerah. Oleh karena itu, akuntabilitas dapat digunakan oleh pemerintah daerah untuk menunjukkan legitimasi mereka guna memperoleh dukungan dari masyarakat.

\section{Gambar 10}

Web Capaian Skor Tingkat Akuntabilitas Pengelolaan Dana Otsus

di Kabupaten Asmat

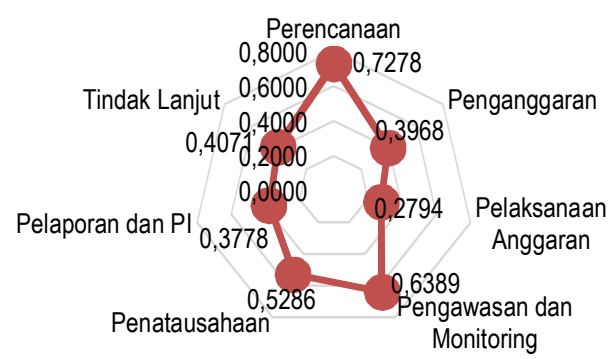

Sumber: Data Primer (diolah, 2013) 
Tingkat akuntabilitas dalam tahap perencanaan penggunaan dana Otsus Kabupaten Asmat dianggap sudah baik. Kegiatan perencanaan merupakan tahapan awal yang dilakukan oleh pemerintah daerah dalam mencari, mengetahui, merumuskan atau memformulasikan hal apa saja yang menjadi permasalahan dan kebutuhan masyarakat untuk dijadikan program kerja yang diharapkan dapat mensejahterakan masyarakat. Pertanyaan diajukan untuk mendapatkan persepsi masyarakat tentang perencanaaan pengelolaan dana Otsus di Kabupaten Asmat, yaitu apakah mereka diundang untuk hadir dalam Musyawarah Rencana Pembangunan Daerah (Musrenbang) di level pemerintahan Distrik atau Kampung.

Dari hasil survei di pihak SKPD, tingkat akuntabilitas dalam tahap perencanaan sudah sangat baik, hal ini ditunjukkan dengan tingkat capaian skor sebesar 1,0000 atau 100 persen. Hal yang tidak terlalu berbeda terdapat dari persepsi lembaga pendidikan dan kesehatan, di mana total capaian skor hanya mencapai 0,4000 atau 40 persen, hal tersebut menunjukkan bahwa tingkat akuntabilitas dalam tahap perencanaan yang menyangkut pendidikan serta kesehatan berjalan dengan cukup baik. Sedangkan dari penilaian individu terhadap tingkat akuntabilitas dalam tahap perencanaan mencapai skor 0,7833 atau 78,33 persen, capaian ini menggambarkan penilaian masyarakat terhadap pelaksanaan Musrenbang dianggap telah merencanakan penggunaan dana Otsus secara baik.

\section{Tabel 9}

Skor Capaian Tingkat Akuntabilitas Pengelolaan Dana Otsus Kabupaten Asmat

\begin{tabular}{|l|c|c|c|}
\hline \multicolumn{1}{|c|}{ Fokus Pengelolaan } & Individu & SKPD & L P\&K \\
\hline Perencanaan & 0,7833 & 1,0000 & 0,4000 \\
\hline Penganggaran & 0,1333 & 0,8571 & 0,2000 \\
\hline Pelaksanaan Anggaran & 0,0667 & 0,5714 & 0,2000 \\
\hline Pengawasan dan Monitoring & 0,7167 & 1,0000 & 0,2000 \\
\hline
\end{tabular}




\begin{tabular}{|l|c|c|c|}
\hline \multicolumn{1}{|c|}{ Fokus Pengelolaan } & Individu & SKPD & L P\&K \\
\hline Penatausahaan & & 0,8571 & 0,2000 \\
\hline Pelaporan dan PI & 0,1333 & 1,0000 & 0,0000 \\
\hline Tindak Lanjut & 0,4500 & 0,5714 & 0,2000 \\
\hline Jumlah Skor & 2,2833 & 5,8571 & 1,4000 \\
\hline Maksimum & 6,0000 & 7,0000 & 7,0000 \\
\hline Pencapaian & 0,3806 & 0,8367 & 0,2000 \\
\hline Prestasi & D & A & D \\
\hline
\end{tabular}

Sumber; Data Primer (diolah, 2013)

Skor capaian untuk tingkat akuntabilitas terendah terdapat pada fokus Pelaksanaan Anggaran yaitu hanya sebesar 0,2794 atau 27,94 persen. Isu akuntabilitas pada tahap pelaksanaan anggaran melihat isu dalam masyarakat adalah bagaimana penilaian mereka terhadap kelompok pendamping kampung, apakah sudah terampil dalam pertanggungjawaban keuangan RESPEK atau tidak. Dari hasil survei terhadap SKPD, capaian skor cukup tinggi yaitu sebesar 0,5714 atau 57,14 persen. Hal ini menunjukkan tingkat akuntabilitas dalam pelaksanaan anggaran di dalam lingkungan SKPD baik, hal ini terjadi karena Pengusaha asli Papua di Kabupaten Asmat telah mendapatkan kerja sesuai amanat Perpres 84 tahun 2012 Pengadaan Barang/Jasa Pemerintah Dalam Rangka Percepatan Pembangunan Provinsi Papua Dan Provinsi Papua Barat. Meskipun pada kenyataannya hal ini masih cukup sulit, sehingga pelaku usaha dari AOP masih didampingi oleh para pelaku usaha yang berasal dari luar Asmat.

Hasil yang sangat berbeda diperoleh dari masyarakat, tingkat pelaksanaan anggaran yang berasal dari dana Otsus sangat tidak memuaskan, hal tersebut dapat terlihat dari capaian skor hanya sebesar 0,0667 atau 6,67 persen. Begitu pun dengan persepsi dari pihak lembaga pendidikan dan kesehatan yang mencapai skor sebesar 0,2000 atau 20 persen, meskipun skornya tidak lebih kecil dibandingkan tingkat capaian masyarakat, namun hasil ini memperlihatkan tingkat akuntabilitas dalam pelaksanaan anggaran masih kurang, karena, misalnya pihak Rumah 
Sakit/Puskesmas tidak dilibatkan oleh Dinas Kesehatan dalam melakukan evaluasi program atas dana Otsus yang digunakan setiap tahun anggaran.

\section{ISU STRATEGIS DAN REKOMENDASI KESIMPULAN DAN SARAN}

\section{Kesimpulan}

a. Tingkat akuntabilitas rendah dalam pelaporan penggunaan dana Otsus menggambarkan rendahnya keinginan Kabupaten Asmat untuk penerapan transparansi pelaporan keuangan. Tidak adanya transparansi penggunaan dana Otsus akan menimbulkan dampak negatif yang sangat luas dan dapat merugikan masyarakat, khususnya di Kabupaten Asmat. Dampak negatif tersebut antara lain dapat menimbulkan ketidaktepatan dalam alokasi sumber daya seperti dana dan manusia, memunculkan ketidakadilan bagi masyarakat, penyalahgunaan wewenang dan kekuasaan. Oleh karena itu perlu pembenahan sistem pengelolaan dana Otsus mulai dari perencanaan sampai dengan tindak lanjut atas temuan pengelolaan. Dalam hal birokrasi maupun administrasi penggunaan dana Otsus perlu dievaluasi dan diperbaiki agar kinerja pengelolaan dana Otsus semakin baik dan dapat meningkatkan efisiensi dan efektivitas dalam perencanaan sampai pertanggungjawaban.

b. Selain itu diperlukan juga untuk meningkatkan transparansi untuk penentuan kebijakan dalam bentuk peraturan yang bisa mewujudkan perbaikan dan meningkatkan akuntabilitas pelaporan keuangan pemerintah daerah. Segala upaya yang bisa dilakukan seperti dengan secara terbuka dan tepat menyediakan semua informasi yang mampu dirilis secara legal baik positif maupun negatif secara akurat, tepat waktu, seimbang, dan tegas, dengan tujuan untuk meningkatkan pemahaman masyarakat, contohnya dengan cara menerbitkan laporan alokasi dana Otsus dalam surat 
kabar lokal atau dengan memajang secara cukup dan jelas dalam Majalah Dinding (Mading) di setiap kantor Pemerintahan yang strategis. Hal tersebut harus dipertimbangkan dan dilakukan agar dapat mengembalikan tingkat kepercayaan publik terhadap pemerintah daerah.

\section{Saran}

Berdasarkan beberapa isu yang diangkat di atas, maka hasil kajian ini dapat merekomendasikan:

a. Pemerintah daerah Kabupaten Asmat melakukan sosialisasi kegiatan yang menggunakan dana Otsus, hal ini merupakan salah satu bentuk transparansi.

b. Dalam hal partisipasi, perlu melibatkan perwakilan dari setiap kampung, tokoh adat, tokoh agama, tokoh perempuan untuk duduk bersama-sama dalam merencanakan kegiatan yang bersumber dari dana Otsus, meskipun selama ini diklaim sudah berjalan, tapi kurang maksimal.

c. Memberikan informasi formal maupun nonformal kepada masyarakat tentang kegiatan apa saja yang menggunakan dana Otsus, seperti mading atau menggunakan teknologi media elektronik, dll.

d. Selalu melibatkan lembaga-lembaga kesehatan maupun pendidikan seperti, puskesmas dan sekolah dalam merencanakan penggunaan dana Otsus sampai pada pertanggungjawaban.

e. Membuat SOP yang khusus dilaksanakan di Kabupaten Asmat dan harus dipastikan SOP tersebut tidak bertentangan dengan Juknis yang telah dikeluarkan dari Provinsi.

f. Melakukan kegiatan yang berkelanjutan dan selalu ada alokasi dana Otsus yang jelas setiap tahun supaya kegiatan yang telah dilakukan tidak berhenti di tengah perjalanan, contohnya sistem pemasaran bagi petani dan nelayan lokal. 


\section{DAFTAR PUSTAKA}

Akuntabilitas Instansi Pemerintah, 2007, Wakhyudi, Ak., M.Comm, Dikeluarkan oleh Pusat Pendidikan dan Pelatihan Pengawasan BPKP dalam rangka Diklat Sertifikasi JFA Tingkat Pembentukan Auditor Anggota Tim, Edisi Ke-5

Bappeda Provinsi Papua. Rencana Definitif Penggunaan Dana Otonomi Khusus Provinsi Papua Tahun Anggaran 2009 s/d Tahun Anggaran 2012, Kabupaten Asmat . Rencana Definitif Penggunaan Dana Otonomi Khusus Provinsi Papua Tahun Anggaran 2009 s/d Tahun Anggaran 2012, Provinsi Papua.

Badan Pusat Statistik Asmat Dalam Angka 2008 s/d 2012 BPS Kabupaten Asmat

http://bagasaskara.wordpress.com/2011/10/12/partisipasi-masyarakatteori-ringkas

http://ovy19.wordpress.com/2010/01/05/sistem-transparansi-danakuntabilitas- terhadap-keuangan-negara

http://manoegra.multiply.com/journal/item 